Iwona Niewiadomska

John Paul II Catholic University of Lublin, Poland

Stanistaw Fel

John Paul II Catholic University of Lublin, Poland

\title{
The Importance of Family Support in the Process of the Adjustment of Current and Former Prisoners
}

\begin{abstract}
The research presented in this paper seeks answers to two questions: What is the impact of perceived support from different actors (including family members) in a situation where problems are encountered in readapting those who have been punished by incarceration? What is the impact of perceived support from different actors (including family members) in achieving the objectives in readapting those who have been punished by incarceration? The answers to these questions are given on the basis of the results obtained by examining 296 men punished by incarceration, who on account of two criteria (location and level of adaptation), were divided into 4 groups: former prisoners with high levels of adaptation, current prisoners with high levels of adaptation, current prisoners with low levels of adaptation and former prisoners with low levels of adaptation. In the determination of the level of adaptation, in the overall result, the RISB Sentence Completion Test by J. Rotter was used, while the sources of support were studied, using the Social Support Rating Questionnaire by I. Niewiadomska.

Based on these results, it may be concluded that perceived family support in overcoming problems and achieving goals - i.e. from the mother, father, siblings, fiancée/wife, relatives - does not contribute to a high level of adaptation, for those who been punished by incarceration, in both current and former prisoners. It is only low-intensely perceived help from one's siblings and fiancée/wife's life, which leads to a reduction of the capabilities for adaptation in people who are currently imprisoned.
\end{abstract}

\section{Keywords}

Families of prisoners, family support, support for prisoners, support for former prisoners, the adaptation of prisoners. 


\section{The Person and the Challenges \\ 166 Volume 5 (2015) Number 2, p. 165-179 \\ 1. Theoretical background research}

The resources of a person in the field of social functioning represent the result of linking its individual characteristics with the "capital" of such groups, which create opportunities for the acquisition of these assets, over the long term ${ }^{1}$. Family values and norms constitute the basic and most important element of social capital in human beings. Only then, the person uses the resources created by other systems, as a result of interpersonal contacts, such as networks of friendship and stable employment ${ }^{2}$. Hence, the family is the key structure of the collective, through which the accumulation and transmission of social capital occurs ${ }^{3}$. The role of the family system in terms of acquiring these resources is based on teaching people prosocial behaviour, including the acceptance of obligations to other people. In contrast, the transmission of social capital in this system is the result of pro-social preferences, values and standards of conduct. There are three mechanisms by which close individuals transmit social capital to individual resources - time and effort invested in the process of socialization, emotional bonds between family members and clearly articulated guidelines for permissible and non-permissible behaviour ${ }^{4}$. It can be argued that "capital family investment of a pro-social nature" contributes to a high level of moral development, which constitutes an important role in reducing criminal behaviour ${ }^{5}$.

Families of repeat offenders do little to shape their social resources. Most of the group had unfavourable conditions of upbringing that most commonly resulted from disorders in their parent-child relationships, the lack of parental supervision, the experience of physical violence and/or sexual abuse, negative patterns of behaviour associated with alcoholism, crime and prostitution ${ }^{6}$. Family studies of repeat offenders also point to a specific way of functioning of family

J. Coleman, Foundations of Social Theory, Harvard 1990, University Press, p. 302.

2 R. Jessor, Successful adolescent development among youth in high-risk settings, "American Psychologist" 48 (1993), p. 117-126.

3 S. Fel, A. Furtak, Status i znaczenie rodziny dla gospodarki w ustroju wolnorynkowym, "Family Forum. Problemy współczesnej rodziny" 1 (2011), p. 118.

4 J. Wright, F. Cullen, J. Miller, Family social capital and delinquent involvement, "Journal of Criminal Justice" 1 (2001), p. 1-9.

Coleman, Foundations of Social Theory, p. 310.

6 L. Simourd, D. Andrews, Correlates of delinquency: A look at gender differences, "Forum on Corrections Research" 6 (1994), p. 26-31. 
systems, in which people, thus reared, repeatedly return to crime. First of all, they are characterized by a low level of internal coherence, resulting, on the one hand, in a low intensity of feeling affection and mutual loyalty, on the other - individual forms of activity, without the participation of other members of that system. In addition, families of repeat offenders are characterized by low adaptability and difficulties in solving problems, due to the rigidity and chaotic functioning of that community. Rigidity is the result of an autocratic leadership style and the stereotyping of accepted roles, whereas the chaotic quality results from an inconsistent control model of upbringing, excessive volatility and liquidity of the applicable standards for performed roles. In addition, in the systems analysed, intra-family communication disorders were found, involving, primarily, the presence of incomprehensible and contradictory messages, the disqualification of information received from interactions with a partner, the lack of empathy and a low capability to maintain an exchange of information? It should be noted, however, that despite having a little social capital, the family constitutes a very important source of support for people with criminal records, both during their stay in prison, and after regaining freedom ${ }^{8}$.

In our study, we raised two questions:

1. What is the impact of perceived support from different actors (including family members) in a situation, where problems are encountered, in readapting those who have been punished by incarceration?

2. What is the impact of perceived support from different actors (including family members) in achieving the objectives, in readapting those who have been punished by incarceration?

\section{Methodology for this study}

Answers to the research questions were based on the findings of a study, with the participation of 296 men, who were punished by incarceration. The respondents were either currently or had, in the past, served time in prison. The division of people with criminal records into current and former prisoners

7 M. Radochoński, Osobowość antyspołeczna. Geneza, rozwój i obraz kliniczny, Rzeszów 2000, Wyd. WSP, p. 199-201.

8 A. Szymanowska, Więzienie i co dalej, Warszawa 2003, Wydawnictwo Akademickie “Żak”, p. 279-283. 
has criminological justification. The location - of current and former prisoners - classifies subjects into those who currently participate in the implementation of sanctions for correctional purposes (convicted offenders in detention) and for those who have already completed the correctional objectives of their penalty (former prisoners) 9 . Only those people for whom at least two years have passed since the end of the last period of incarceration, formed the sample population of former inmates. The adoption of this criterion is warranted by the results of studies that have found that a period of up to 2 years after leaving prison is associated with a high likelihood of recidivism, and the longer duration of stay away from prison can attest to the completion of the correctional purposes for imprisonment, due to significantly lower risk of committing crime again ${ }^{10}$.

The study had a twofold character, on the basis of the place of residence of persons convicted. The first way depended upon reaching the convicted men who were in the process of imprisonment. The study was conducted in three male penitentiaries of the Lublin Inspectorate of Prison Service: the closed prison for first offenders in Zamosc, the closed unit in Chelm, which was designed for convicts who are first offenders or penitentiary recidivists, as well as a prison institution of the closed and semi-open variety for repeat offenders in Wlodawa. The second research method concerned men, for whom the penalty of incarceration had concluded. The studies were conducted across all of Poland, and the outreach to these subjects was conducted on the basis of recommendations by probation officers, priests, members of AA and social workers.

The level of adaptation of current and former prisoners was determined on the basis of the outcome of the RISB General Sentence Completion Test by J. Rotter, that reflects a person's adaptive capabilities in areas such as: functioning in relationships outside the family, the way of functioning in family relationships, their relationship with themselves, their aspirations and goals, and the severity of the problems that they have experienced ${ }^{11}$. The psychometric value of the method that was measured according to the the $\alpha$-Cronbach ratio of internal

9 C. Clements, Offender classification: Two decades of progress, "Criminal Justice and Behavior" 23 (1996), p. 121-143.

10 P. Dynia, H. Sung, The Safety and Effectiveness of Diverting Felony Drug Offenders to Residential Treatment as Measured by Recidivism, "Criminal Justice Policy Review" 4 (2000), p. 299-311.

11 A. Jaworowska, A. Matczak, Test Niedokończonych Zdań Rottera (RISP). Podręcznik, Warszawa 1998, PTP. 
compliance for the overall score is $0.79^{12}$. The accuracy measured in differences in the contrasting groups indicates that unsuitable people (prisoners, battered women, patients with depression, the unemployed) achieve a significantly lower level of adaptability than the people in the control sample ${ }^{13}$. The isolation of the surveyed population of such persons, which is characterized by a high and a low level of adaptation, was carried out through the use of quartile deviation with respect to the outcome of the RISB General Sentence Completion Test. By using this treatment for analysis, results were selected from amongst the people who received $25 \%$ of the minimum and $25 \%$ of the maximum provided results indicating the level of adaptation of persons enduring sanctions of incarceration currently, or in the past.

The next step, aimed at the division of the respondents, was the use of cross tables. Thanks to this procedure, 4 groups were selected, which also take into account the interdependencies that occur between the place of residence and the level of adaptation of inmates in prison. Because of the two criteria mentioned above (place of residence of persons with criminal records: being in prison or outside it), and adaptation level: (high or low) subjects were divided into four groups:

Group A $(n=47)$ - former prisoners with a high level of adaptation

Group B $(n=26)$ - current prisoners with a high level of adaptation

Group C ( $n=44)$ - current prisoners with low levels of adaptation

Group D ( $\mathrm{n}=34)$ - former prisoners with low levels of adaptation.

The study of perceived sources of support in solving problems and achieving goals used the Social Support Rating Questionnaire by I. Niewiadomska ${ }^{14}$. The method is based on several assumptions. First, in stressful situations people use social support in varying degrees, which is actually a "buffer" for the negative effects of stress. The second is related to it, in that perceived support depends on the circumstances leading to mental tension, the needs of people who are experiencing problems and/or who aim to achieve the objectives, as well as the characteristics and availability of social networks. The third results from the fact that the perceived aid is often reported as a sense of obtained

12 A. Matczak, A. Jaworowska, Test Niedokończonych Zdań Rottera RISB. Aneks do podręcznika. Normalizacja dla osób dorostych, Warszawa 2003, PTP, p. 11-12.

13 Matczak, Jaworowska, Test Niedokończonych Zdań Rottera RISB. Aneks do podręcznika. Normalizacja dla osób dorostych, p. 13-29.

14 I. Niewiadomska, Osobowościowe uwarunkowania skuteczności kary pozbawienia wolności, Lublin 2007, Wyd. KUL, p. 344-345. 
support ${ }^{15}$. The questionnaire listed two categories of actors that can provide support to the person examined: 1) individuals (9 types of entities) - mother, father, siblings, relatives, fiancée/wife, colleagues, teachers, priests, other people; 2) institutions that can provide assistance (4 types of entities) - school, parish, municipality, other centres. The $\alpha$-Cronbach internal compliance factor, calculated on a group of 296 people for the indicator of currently experienced support with their perceived problems reached: $0.79^{16}$.

To seek answers to research questions, the ANOVA analysis of variance was used ${ }^{17}$.

\section{Our results}

The answer to the first research question - What is the impact of perceived support from different actors (including family members) in a situation, where problems are encountered in readapting those who have been punished by incarceration? - was based on the results contained in Table 1. By contrast, the results contained in Table 2 provide the basis for answering the question: What is the impact of perceived support from different actors (including family members) in achieving the objectives in readapting those who have been punished by incarceration?

15 H. Sęk, R. Cieślak, Test Niedokończonych Zdań Rottera RISB. Aneks do podręcznika. Normalizacja dla osób dorostych, in: H. Sęk, R. Cieślak (eds.), Wsparcie społeczne, stres i zdrowie, Warszawa 2004, Wyd. Nauk. PWN, p. 11-28. p. 345 .

${ }_{16}$ Niewiadomska, Osobowościowe uwarunkowania skuteczności kary pozbawienia wolności,

17 G. Ferguson, Y. Tkane, Analiza statystyczna w psychologii i pedagogice, Warszawa 1997, Wyd. Nauk. PWN, p. 272-273. 


\section{Comparison of perceived sources of support in solving problems by former and current prisoners with different levels of adaptation}

Table 1. The results of the analysis of variance (general linear model, GLM) serve to compare perceived support from individuals and institutional actors in a situation of experiencing problems in four test groups, that were separated on the basis of the place of residence of the convicted persons and the adaptive potential they possessed - Groups A, B, C, D

\begin{tabular}{|c|c|c|c|c|c|c|c|c|c|c|c|c|c|c|c|}
\hline \multirow[t]{2}{*}{$\begin{array}{l}\text { The source } \\
\text { of perceived } \\
\text { support }\end{array}$} & \multicolumn{2}{|l|}{ Control } & \multicolumn{2}{|c|}{$\begin{array}{l}\text { Groups } \\
\text { A, B, C, D } \\
\text { Source of } \\
\text { change of } \\
\text { dep. variable }\end{array}$} & \multicolumn{2}{|c|}{$\begin{array}{l}\text { Group } \\
A(n=47)\end{array}$} & \multicolumn{2}{|c|}{$\begin{array}{l}\text { Group } \\
B(n=26)\end{array}$} & \multicolumn{2}{|c|}{$\begin{array}{l}\text { Group } \\
C(n=44)\end{array}$} & \multicolumn{2}{|c|}{$\begin{array}{l}\text { Group } \\
D(n=34)\end{array}$} & \multirow{2}{*}{$\begin{array}{r}A-B \\
p \leq\end{array}$} & \multirow{2}{*}{$\begin{array}{l}A-C \\
p \leq\end{array}$} & \multirow{2}{*}{$\begin{array}{l}\text { A-D } \\
p \leq\end{array}$} \\
\hline & $F$ & $p \leq$ & $F$ & $\mathbf{p} \leq$ & M & $S$ & M & $S$ & M & s & M & s & & & \\
\hline Mother & 545,68 & ,000 & 1,39 & ,248 & 3,06 & 1,65 & 3,46 & 1,42 & 2,68 & 1,65 & 3,00 & 1,41 & - & - & - \\
\hline Father & 361,34 &, 000 &, 56 & 641 & 2,26 & 1,55 & 2,38 & 1,50 & 2,07 & 1,28 & 2,47 & 1,44 & - & - & - \\
\hline Siblings & 613,40 & ,000 & 2,40 & ,071 & 3,04 & 1,43 & 2,96 & 1,28 & 2,34 & 1,26 & 2,68 & 1,32 & - & ,013 & - \\
\hline Kin & 492,11 & , 000 & ,72 &, 544 & 2,47 & 1,36 & 2,12 & 1,18 & 2,16 & 1,10 & 2,21 & 1,12 & - & - & - \\
\hline Fiancée/Wife & 531,52 & ,000 & 1,39 & ,249 & 3,23 & 1,49 & 3,04 & 1,48 & 2,59 & 1,63 & 2,91 & 1,46 & - & ,046 & - \\
\hline Colleagues & 625,14 & , 000 & 2,98 & ,034 & 2,96 & 1,18 & 2,46 & 1,39 & 2,20 & 1,09 & 2,56 & 1,28 & - & ,004 & - \\
\hline Educators & 361,00 & ,000 & 1,18 & ,320 & 1,60 & 1,03 & 1,73 & 1,00 & 1,48 & ,90 & 1,91 & 1,29 & - & - & - \\
\hline Triest & 362,04 & , 000 & 4,33 & ,006 & 2,26 & 1,29 & 1,62 & 1,02 & 1,45 & ,93 & 1,78 & 1,32 & ,026 & ,001 & ,036 \\
\hline Other people & 320,89 & ,000 & 1,92 & ,129 & 2,06 & 1,32 & 1,73 & 1,12 & 1,52 & 1,07 & 2,06 & 1,37 & - & ,038 & - \\
\hline Schol & 387,40 &, 000 & 1,75 &, 160 & 1,36 & 84 & 1,62 & ,90 & 1,30 & 67 & 1,71 & 1,22 & - & - & - \\
\hline Parish & 440,01 & ,000 & 5,20 & ,002 & 1,68 & 1,04 & 1,46 & 81 & 1,07 & , 25 & 1,71 & 1,03 & - & ,001 & - \\
\hline Community & 403,14 & ,000 & 3,50 & 017 & 1,57 & ,99 & 1,35 &, 56 & 1,23 & ,71 & 1,85 & 1,13 & - & - & - \\
\hline $\begin{array}{l}\text { Other } \\
\text { institutions }\end{array}$ & 346,87 &, 000 & 3,18 & ,026 & 1,70 & 1,10 & 1,54 & ,99 & 1,18 & ,49 & 1,82 & 1,31 & - & ,015 & - \\
\hline
\end{tabular}

Legend:

Group A - former prisoners with a high adaptive potential

Group B - current prisoners with a high adaptive potential

Group $\mathrm{C}$ - current prisoners with a low adaptive potential

Group D - former prisoners with a low adaptive potential

On the basis on the results presented in this table, several assertions can be made with some reliability. Firstly, in each of the compared groups (A, B, C, D) perceived support from individuals for solving current problems was more often cited than support of an institutional nature - i.e. from parishes, municipalities, schools, or other institutions.

Secondly, the perception of sources of support for overcoming problems most strongly differentiates individuals who are currently imprisoned, and are characterized by low adaptation (group C). Prisoners characterized by low 
levels of adaptation (group C), perceive support at a significantly lower level, compared to the other groups (A, B, D) from:

- physical entities such as: priest, siblings, friends, fiancée/wife, other people;

- such entities as: parish, other institutions.

Thirdly, it can be concluded that the perception of support from a priest while experiencing difficulties affects the high level of adaptation in the conditions of those who are free. The presented conclusion follows from the results, in which the perception of support from a member of the clergy in a situation involving overcoming difficulties is significantly more often felt by former prisoners with a high potential for adaptation, in relation to the other three groups (current prisoners with great and low adaptive capacity - Groups B, C), and former inmates with little adaptive potential (group D).

Fourthly, the perceived source of aid is hardly differentiated according to the level of adaptation of former prisoners. Namely, apart from the difference involving the support of the priest, those who were convicted having both high and low possibilities of adaptive experience in problem situations perceive in a similar manner the support of: mother, father, siblings, relatives, fiancée/ wife, colleagues, teachers, other individuals, schools, parishes, municipalities and other institutions.

Fifthly, those characterized by a high intensity of adaptation, regardless of the place of residence (both in prison, as well as in conditions of freedom) perceive in a similar way the source of help that comes to them for solving problems (with the exception of a significant difference in the perceived support of the priest). There is no significant indication of differences between the two groups compared (A and B) in the perceived support in problem situations from: mother, father, siblings, relatives, fiancée/wife, colleagues, teachers, other people, schools, parishes, municipalities and other institutions.

Sixthly, the family support felt by the mother, father and relatives is at a similar level in all comparison groups, i.e. with former prisoners with low and high intensity of adaptation (groups A, D) and those who are currently serving prison sentences, having high and low adaptive possibilities (groups $\mathrm{B}, \mathrm{C})$. There were patterns of results indicating that the perceived help from the mother, father and relatives in the situation of experiencing problems does not affect the adaptation of people who have been punished in incarceration.

Seventhly, a low perception of family support from siblings and one's fiancée/ wife has an important impact on the low adaptation of current prisoners. By contrast, it does not affect the level of adaptation in the case of the free, nor 
to the high adaptability of the currently incarcerated (the results in groups A, $\mathrm{B}$ and $\mathrm{D}$ are at a comparable level).

\section{Comparison of the perceived sources of support in achieving goals by former and current prisoners from different levels of adaptation}

Table 2. The results of an analysis of variance (general linear model GLM) for comparison of perceived support from individuals and institutional entities in achieving success in four test groups that were separated because of the place of residence of the persons convicted and the adaptive potential that they possess - Groups A B, C, D

\begin{tabular}{|c|c|c|c|c|c|c|c|c|c|c|c|c|c|c|c|}
\hline \multirow[t]{2}{*}{$\begin{array}{l}\text { The source } \\
\text { of perceived } \\
\text { support }\end{array}$} & \multicolumn{2}{|l|}{ Control } & \multicolumn{2}{|c|}{$\begin{array}{l}\text { Groups } \\
\text { A, B, C, D } \\
\text { Source of } \\
\text { change of } \\
\text { dep. variable }\end{array}$} & \multicolumn{2}{|c|}{$\begin{array}{l}\text { Group } \\
A(n=47)\end{array}$} & \multicolumn{2}{|c|}{$\begin{array}{l}\text { Group } \\
B(n=26)\end{array}$} & \multicolumn{2}{|c|}{$\begin{array}{l}\text { Group } \\
C(n=44)\end{array}$} & \multicolumn{2}{|c|}{$\begin{array}{l}\text { Group } \\
D(n=34)\end{array}$} & \multirow{2}{*}{$\begin{array}{l}A-B \\
p \leq\end{array}$} & \multirow{2}{*}{$\begin{array}{l}A-C \\
p \leq\end{array}$} & \multirow{2}{*}{$\begin{array}{l}A-D \\
p \leq\end{array}$} \\
\hline & $F$ & $\mathbf{p} \leq$ & $F$ & $\mathbf{p} \leq$ & M & S & M & s & M & $S$ & M & $S$ & & & \\
\hline Mother & 419,43 & ,000 & ,90 & ,441 & 2,66 & 1,65 & 3,04 & 1,56 & 2,41 & 1,65 & 2,76 & 1,44 & - & - & - \\
\hline Father & 331,38 & 000 & 1,85 & ,141 & 2,23 & 1,52 & 2,27 & 1,54 & 1,80 & 1,21 & 2,56 & 1,58 & - & - & - \\
\hline Siblings & 475,12 & ,000 & 1,83 & , 144 & 2,66 & 1,49 & 2,77 & 1,34 & 2,09 & 1,20 & 2,53 & 1,46 & - & - & - \\
\hline Kin & 401,22 & ,000 & 80 & ,496 & 2,30 & 1,50 & 2,23 & 1,24 & 1,93 & 1,11 & 2,32 & 1,32 & - & - & - \\
\hline Fiancée/Wife & 502,80 & 000 & 2,68 & 049 & 3,38 & 1,45 & 2,96 & 1,61 & 2,48 & 1,66 & 2,79 & 1,47 & - & ,006 & - \\
\hline Colleagues & 536,90 & ,000 & 2,75 & , 045 & 2,68 & 1,29 & 2,42 & 1,39 & 1,95 & 1,10 & 2,44 & 1,16 & - & ,005 & - \\
\hline Educators & 389,85 & ,000 & 2,78 & ,043 & 1,64 & 1,00 & 1,50 & 86 & 1,34 & ,68 & 1,97 & 1,29 & - & - & - \\
\hline Priest & 363,68 & ,000 & 4,85 & ,003 & 1,81 & 1,23 & 1,58 & ,81 & 1,14 & ,46 & 1,91 & 1,29 & - & ,002 & - \\
\hline Other people & 351,34 & 000 & 2,33 & 077 & 1,91 & 1,23 & 1,65 & ,94 & 1,39 & ,94 & 1,94 & 1,20 & - & ,023 & - \\
\hline School & 376,49 & ,000 & 2,43 & 067 & 1,47 & ,97 & 1,46 & 81 & 1,20 &, 55 & 1,76 & 1,21 & - & - & - \\
\hline Parish & 443,18 & ,000 & 4,34 & 006 & 1,55 & 1,02 & 1,35 & 69 & 1,09 & ,36 & 1,71 & ,97 & - & ,007 & - \\
\hline Community & 452,88 & ,000 & 5,32 & 002 & 1,40 & 82 & 1,31 & ,68 & 1,14 &, 51 & 1,85 & 1,10 & - & - &, 014 \\
\hline $\begin{array}{l}\text { Other } \\
\text { intitutions }\end{array}$ & 343,51 & ,000 & 2,27 & ,083 & 1,43 & 88 & 1,50 & ,99 & 1,23 &, 74 & 1,79 & 1,25 & - & - & - \\
\hline
\end{tabular}

Legend:

Group A - former prisoners with a high adaptive potential

Group B - current prisoners with a high adaptive potential

Group C - current prisoners with a low adaptive potential

Group D - former prisoners with a low adaptive potential

Analysis of the results relating to actors giving support in carrying out the current efforts pointed to:

- a significantly lower frequency of received support from one's fiancée/ wife, colleagues, priest and parish in the current population of prisoners with low intensity of adaptation (group C) relative to population B (current 
prisoners with high adaptive capacity), A (former prisoners with high adaptation), and D (former prisoners with low intensity of adaptation);

- a significantly higher frequency of perceived support from the municipalities in the community of former prisoners with little potential adaptivity (group D) in relation to groups: A (former prisoners with high adaptive capacity), $\mathrm{B}$ and $\mathrm{C}$ (current prisoners with high and low levels of adaptation).

The first regular tendency points to the fact that a low frequency of support from the four entities in the pursuit of their current objectives - fiancée/wife, colleagues, priest and parish - determines the low adaptive potential for those who are still in prison. On the basis of this dependence, a high rate of adaptation cannot however be inferred, due to the lack of differences between populations A, B and D.

The second of the obtained regular tendencies attests to the fact that a high frequency of use of the support provided by the municipality affects a lessening of the ability for adaptation of those who are free. The result obtained, however, does not constitute grounds for concluding that the impact of this factor on their high adaptive capacity, due to comparable results in groups A, B and C.

Perceived family support-including from the mother, father, siblings, relatives - does not affect the adaptation of people who have been in incarceration. This conclusion was based on the similarity of the results of the aforementioned factors compared in four groups - current prisoners with low and high adaptive potential (group B, C) and former prisoners with high and low levels of adaptation (groups A, D). Only the family support on the part of the fiancée/ wife has a conclusive impact on the level of adaptation, for those who have been punished by incarceration. As mentioned above, the low intensity of this factor is determinant with respect to the low capacity for adaptation by people who are currently imprisoned. However, it does not affect either the high level of adaptation of current prisoners, nor on the level of adaptation in people who have left prison.

\section{Conclusion}

The findings of this study lead to the conclusion that perceived family support - including from the mother, father, siblings, fiancée/wife, relatives - does not contribute to an increase in the level of adaptation neither in the population of current prisoners nor in that of those who have left prison. It 
is only the perceived support of mild intensity from siblings and a fiancée/ wife which results in a lower adaptive capacity for those currently detained in prison. It can be concluded that those who have been punished by incarceration - irrespective of their location and level of adaptation - experienced the support of family members at a similar level, both with respect to overcoming problems, as well as to achieving important goals. However, aid granted by close ones does not contribute to an increase in the level of adaptation, neither of current prisoners, nor of former convicts.

On the basis of the obtained results, a postulate can thus be formulated, based on the fact that in order to seek different forms of shaping and/or strengthening of social capital amongst the family members of people with criminal records of incarceration - amongst whom are the parents, siblings, fiancée/wife - the support provided by those who are closest to the prisoner should contribute to an increase in the level of adaptation by inmates, both during the imprisonment, and after its completion.

Supportive arguments for the implementation of this postulate point to a strong relationship between the intensity of experienced social support and the level of human adaptation:

Argument 1.: Overcoming personal difficulties is often combined with the possibility of taking advantage of the assistance of social resources. Therefore, the support environment can be regarded as a coping strategy: its element, a resource or a mediator in the dynamics of coping with stress ${ }^{18}$. The positive role of other people in overcoming a difficult situation is all the greater: the more help is appropriate and expected, and the more a person sees a connection between a positive change in his own situation and positive reinforcement from others ${ }^{19}$.

Argument 2.: The importance of social support for the functioning of a person can be of a generally immunizing or buffering character. The immunizing role lies in the fact that the assistance provided of an informational, emotional, instrumental or factual nature is perceived and evaluated in terms of how it allows for the overcoming of difficulties, leading both to alleviating stress, as well as to enlarging one's individual counteractive resources. The results of

18 S. Koole, W. Jager, A. Berg, C. Vlek, W. Hofstee, On the Social Nature of Personality: Effects of Extraversion, Agreeableness, and Feedback about Collective Resource Use on Cooperation in a Resource Dilemma, "Society for Personality and Social Psychology" 3 (2001), p. 289-301.

19 K. Kmiecik-Baran, Skala wsparcia społecznego. Teoria i właściwości psychometryczne, "Przegląd Psychologiczny" 1-2 (1995), p. 201-214. 
the empirical analysis - that perceived social support correlates positively with task-oriented remedies, and negatively with one's emotional state - confirm the correctness of that which is presented. By contrast, the absence of external support in difficult situations, on the one hand, comes down to the severity of the stressor's action, on the other hand - to a drop in the individual capacity to cope with the stressor. It is also important that the person experiencing help from others feels safe and rooted in the community, which in the long run leads to an increase his resistance to stress ${ }^{20}$.

Argument 3: The perception and receipt of social support in situations of severe stress protects the person from pathology in physiological, psychological and/or social functioning. The buffering effect of the assistance relationship can be diverse in nature, depending on what element the dynamic of the stress acts. Its role may depend upon changes in the initial assessment of the stress response - i.e. a person undertakes a transformation of the opinion of the type of loss and the threat to another - the type of challenge. The protective effect of support may also be noted in the secondary assessment of the dynamics of stress - i.e. thanks to this feedback, the person undergoes a changes of mind about his own competence, obtains insight into his own abilities, increases the sense of his resourcefulness, and thereby copes effectively with the ensuing problems. The buffering effect of assistance relationships may also involve reducing psychological tension, or weakening the negative effects of stress ${ }^{21}$.

Argument 4.: The feeling of support is largely dependent on a person's trust with specific contacts. Its lack most commonly stems from the belief that people investing personal resources in the relationship bring with them a high risk of unfavourable results for the "investor." The motivation to initiate a relationship based on trust is particularly low in a situation where a person has experienced in the past: that the risk of investing his own resources proved to be too great, due to the low credibility of the partner ${ }^{22}$. It appears that this type of motivation is characteristic of the perception of social support by prisoners serving in incarceration. The results indicate that the probability of reversion to the crime

${ }^{20}$ H. Sęk, Rola wsparcia spolecznego w sytuacjach stresu życiowego. O dopasowaniu wsparcia do wydarzeń stresowych, in: H. Sęk, R. Cieślak (eds.), Wsparcie społeczne, stres i zdrowie, Warszawa 2004, Wyd. Nauk. PWN, p. 49-67.

${ }_{21}$ H. Sęk, Rola wsparcia społecznego w sytuacji kryzysu, in: D. Kubacka-Jasiecka, T. Ostrowski (eds.), Psychologiczny wymiar zdrowia, kryzysu i choroby, Kraków 2005, Wyd. UJ, p. 87-107.

22 T. Gautschi, History Effects in Social Dilemma Situations, "Rationality and Society" 2 (2000), p. 131-162. 
falls in a situation where the person expects that after release from prison, his pro-social behaviour will be associated with having friends, the stabilization of life and personal happiness. However, a low level of mutual trust between the former prisoner and members of conventional social groups leads to the fact that a person previously convicted withdraws from interpersonal contact, and does not use social support resources, mainly for fear of another failure. Empirical studies also lead to the conclusion that one of the most common ways of dealing with social rejection is to avoid a situation in which a person comes into contact with stigmatization. The presented strategy on the one hand protects the former prisoner against an increase in negative self-esteem and reduces the sense of danger, but on the other - reduces the number and/or quality of constructive contacts with people ${ }^{23}$.

The importance of social support for people who have been in incarceration was highlighted in the theory of the reintegration of shame, which is increasingly being used in the re-socialization of people leaving prison. This concept implies that an important mechanism for regulating the behaviour of repeat offenders is shame, which can either lead to positive social reintegration, or to re-offending. Shame can re-integrate, under the following conditions:

- community members openly express their disapproval of those acts, which are contrary to the law, while showing respect for its perpetrators,

- there was an officially certified termination of the penalty for the offence,

- the act committed is not a deciding factor, for the offender to achieve social status ${ }^{24}$.

Compliance with these conditions leads to the establishment and/or strengthening of various types of commitments between the collectivity and the former prisoner, which, on one hand, promotes a positive reintegration, on the other - reduces the risk of stigmatization that leads to a deviant identity and related behaviour ${ }^{25}$. Both these factors - the strengthening of the commitment towards the environment and the weakening of the stigma - contribute to the greater effectiveness of the penalty of incarceration.

23 B. Geiger, M. Fischer, Naming Oneself Criminal: Gender Difference in Offenders' Identity Negotiation, "International Journal of Offender Therapy and Comparative Criminology" 2 (2005), p. $194-209$.

${ }_{24}$ T. Makkai, J. Braithwaite, Reintegrative shaming and compliance with regulatory standards, "Criminology" 32 (1994), p. 361-383.

${ }^{25}$ L. Zhang, S. Zhang, Reintegrative Shaming and Predatory Delinquency, "Journal of Research Crime and Delinquency" 4 (2004), p. 433-453. 


\section{Bibliography}

Braithwaite J., Crime, shame and reintegration, Cambridge 1989, University Press.

Clements C., Offender classification: Two decades of progress, "Criminal Justice and Behavior" 23 (1996), p. 121-143.

Coleman J., Foundations of Social Theory, Harvard 1990, University Press.

Dynia P., Sung H., The Safety and Effectiveness of Diverting Felony Drug Offenders to Residential Treatment as Measured by Recidivism, "Criminal Justice Policy Review" 4 (2000), p. 299-311.

Fel S., Furtak A., Status i znaczenie rodziny dla gospodarki w ustroju wolnorynkowym, "Family Forum. Problemy współczesnej rodziny" 1 (2011), p. 111-131.

Ferguson G., Tkane Z., Analiza statystyczna w psychologii i pedagogice, Warszawa 1997, Wyd. Nauk. PWN.

Gautschi T., History Effects in Social Dilemma Situations, "Rationality and Society" 2 (2000), p. 131-162.

Geiger B., Fischer M., Naming Oneself Criminal: Gender Difference in Offenders' Identity Negotiation, "International Journal of Offender Therapy and Comparative Criminology" 2 (2005), p. 194-209.

Jaworowska A., Matczak A., Test Niedokończonych Zdań Rottera (RISP). Podręcznik, Warszawa 1998, PTP.

Jessor R., Successful adolescent development among youth in high-risk settings, "American Psychologist" 48 (1993), p. 117-126.

Kmiecik-Baran K., Skala wsparcia społecznego. Teoria i właściwości psychometryczne, "Przegląd Psychologiczny" 1-2 (1995), p. 201-214.

Koole S., Jager W., Berg A., Vlek C., Hofstee W., On the Social Nature of Personality: Effects of Extraversion, Agreeableness, and Feedback about Collective Resource Use on Cooperation in a Resource Dilemma, "Society for Personality and Social Psychology" 3 (2001), p. 289-301.

Makkai T., Braithwaite J., Reintegrative shaming and compliance with regulatory standards, "Criminology" 32 (1994), p. 361-383.

Matczak A., Jaworowska A., Test Niedokończonych Zdań Rottera RISB. Aneks do podręcznika. Normalizacja dla osób dorostych, Warszawa 2003, PTP.

Niewiadomska I., Osobowościowe uwarunkowania skuteczności kary pozbawienia wolności, Lublin 2007, Wyd. KUL.

Niewiadomska I., Zakorzenianie społeczne więźniów, Lublin 2011, Wyd. KUL.

Niewiadomska I., Chwaszcz J., Jak skutecznie zapobiegac karierze przestepczej?, Lublin 2010, Wyd. Zonik i ska.

Radochoński M., Osobowość antyspołeczna. Geneza, rozwój i obraz kliniczny, Rzeszów 2000, Wyd. WSP.

Sęk H., Rola wsparcia społecznego w sytuacji kryzysu, in: D. Kubacka-Jasiecka, T. Ostrowski (eds.), Psychologiczny wymiar zdrowia, kryzysu i choroby, Kraków 2005, Wyd. UJ, p. 87-107.

Sęk H., Rola wsparcia społecznego w sytuacjach stresu życiowego. O dopasowaniu wsparcia do wydarzeń stresowych, in: H. Sęk, R. Cieślak (eds.), Wsparcie społeczne, stres i zdrowie, Warszawa 2004, Wyd. Nauk. PWN, p. 49-67. 
Iwona Niewiadomska, Stanisław Fel

Sęk H., Cieślak R., Wsparcie społeczne - sposoby definiowania, rodzaje i źródła wsparcia, wybrane koncepcje teoretyczne, in: H. Sęk, R. Cieślak (eds.), Wsparcie spoleczne, stres i zdrowie, Warszawa 2004, Wyd. Nauk. PWN, p. 11-28.

Simourd L., Andrews D., Correlates of delinquency: A look at gender differences, "Forum on Corrections Research" 6 (1994), p. 26-31.

Szymanowska A., Więzienie i co dalej, Warszawa 2003, Wyd. Akadem. “Żak”.

Wright J., Cullen F., Miller J., Family social capital and delinquent involvement, "Journal of Criminal Justice" 1 (2001), p. 1-9.

Zhang L., Zhang S., Reintegrative Shaming and Predatory Delinquency, "Journal of Research Crime and Delinquency" 4 (2004), p. 433-453. 